\title{
The Virtues
}

\section{P. T. GEACH}

Professor Geach looks afresh at the seven traditional virtues: faith, hope, charity, prudence, justice, temperance and courage. He argues that they are indeed virtues, and that we do need virtues - not through inclination or duty, but because of what we are. The book is intended for a general readership, and is written with characteristic wit and trenchancy.

$£ 4.95$ net

\section{Providence and Evil}

\section{P. T. GEACH}

Providence and Evil deals with some of the oldest and most intractable problems in theology and the philosophy of religion. If the world is planned in all its detail by a mind, can that mind be called good, given the world's actual nature? Professor Geach's argument is in striking contrast, both in style and substance, to the concessive uncertainties of most recent Christian apologetics.

SOCIETY FOR NEW TESTAMENT STUDIES: MONOGRAPH SERIES 32

\section{On the Independence of Matthew and Mark}

\section{J. M. RIST}

It has long been generally assumed that the relationship between the texts of the Gospels of Matthew and Mark is to be explained in terms of direct literary dependence, either of Matthew on Mark, or of Mark on Matthew. Professor Rist vigorously questions this assumption, and argues that it leads to contradictory and paradoxical conclusions.

About $\mathbf{£ 5 . 0 0}$ net

\section{The Origin of Christology}

\section{F. D. MOULE}

This book is about the processes by which Christians of the first century came to experience and understand Jesus as they did. Some writers represent these processes as 'evolutionary'; Professor Moule, on the other hand, shows that 'development' is a preferable analogy to evolution. It is not that a new species of figure was evolved, but that understanding of what there was in Jesus from the beginning developed in various ways and on various levels.

About $\mathbf{1 7 . 0 0}$ net

\section{CAMBRIDGE UNIVERSITY PRESS}




\section{God B.C.}

\section{Anthony Phillips}

Here is a lucid and original account of the stages in the Israelites' understanding of the God with whom they had to deal: God B.C. Dr Phillips lays bare the essential nature of Old Testament belief, in a cogent analysis of the Book of Job, and explains how the New Testament confirms the Old in revealing the one unchanging God in the person of Jesus Christ, "who acknowledges as his father the jealous God of Sinai'. $£ 2.50$ Oxford Paperbacks 95p

\section{Divine Substance \\ G. C. Stead \\ The concept of substance plays an important part in ancient philosophy no less than in the classical statements of Christian theology. This book covers the whole field in detail and gives a critical account of the develop- ment of the Christian doctrine of God. It is fully documented; the principal texts are given in the original languages but all Greek words have been translated or paraphrased. $£ 12.50$ \\ The Cartulary of Cirencester Abbey, Gloucestershire Volume 3 Edited by Mary Devine}

The manuscript Cartulary of Cirencester Abbey, previously unpublished, is in the Bodleian Library. The text has now been printed with an introductory summary in English at the head, and brief textual and historical notes at the end, of each document. For the specialist in medieval history this collection makes available many charters of considerable interest. This third volume completes the publication. $£ 15$

\section{The Letters and Diaries of John Henry Newman}

Volume XXXI: The Last Years, January 1885 to August 1890

\section{Edited by the late Charles Stephen Dessain and Thomas Gornall, S.J.}

Volume XXXI concludes the publication of the larger part of Newman's Letters and Diaries, those of his Catholic period. Volumes I-X will contain the letters of which Anne Mozley printed extracts, together with the rest of the letters written by Newman as an Anglican. $£ 18.50$

\section{Oxford University Press}




\section{NOTES FOR CONTRIBUTORS}

I. Contributions and books for review should be sent to the Editor, Professor H. D. Lewis, King's College, Strand, London, wG2R 2Ls. Books published in America should be sent to Professor J. E. Smith, Department of Philosophy, Yale University, New Haven.

2. Articles submitted to the journal should in general be between 5,000 and I0,000 words long, though articles outside these limits will be acceptable if there is some good reason for their exceptional length or brevity. Articles in two or more parts may occasionally be accepted provided each part is independently intelligible. They should normally be in English.

3. Submission of an article is taken to imply that it has not previously been published, or is not being considered for publication elsewhere.

4. Contributions should be clearly typed in double spacing, preferably on $\mathrm{A}_{4}$ paper, with a wide left-hand margin. The typescript should be prepared to accord as closely as possible with the typographical conventions of the journal.

5. Footnotes should be used sparingly: in general, to give sources of direct quotations, references to main authorities on disputable questions, and evidence relied on for a new or unusual conclusion. They should be numbered in one sequence throughout the article, and should preferably be typed in double spacing at the end of the article.

6. Contributors should keep one copy of the typescript for correcting proofs.

7. First proofs may be read and corrected by contributors provided that they can give the Editor an address through which they can be reached without delay and can guarantee to return the corrected proofs to the Editor, by airmail where necessary, within ten days of receiving them.

8. Correction should be kept to an absolute minimum. It should be confined to errors of the typist or printer unless the Editor authorises otherwise.

9. All contributors of articles receive 50 free offprints. Reviewers will receive five or more offprints of their reviews.

Io. If rejected manuscripts are to be returned, stamps or international coupons should be sent to cover postage.

I I. Contributors of accepted articles will be asked to assign their copyrights, on certain conditions, to Cambridge University Press, to help protect their material, particularly in the USA. 


\section{Religious Studies}

Volume 13, Number 2, June 1977

\section{GONTENTS}

\section{PENELHUM, TERENCE}

The Analysis of Faith in St Thomas Aquinas

HARTSHORNE, GHARLES

John Hick on Logical and Ontological Necessity

OAKES, ROBERT A.

Classical Theism and Pantheism: A Victory for Process

Theism?

JOHNSON, GALEN A.

Hartshorne's Arguments Against Empirical Evidence for

Necessary Existence: An Evaluation

HICK, JOHN

Eschatological Verification Reconsidered

CHRISTIAN, WILLIAM A.

Bochenski on the Structure of Schemes of Doctrines

HUDSON, W. D.

What Makes Religious Beliefs Religious?

LIPNER, J. J.

Does Copernicus Help? Reflections for a Christian Theology of Religions

Reviews

(C) Cambridge University Press 1977

CAMBRIDGE UNIVERSITY PRESS

Bentley House, 200 Euston Road, London NWI 2DB

32 East 57 th Street, New York, N.Y. 10022

Religious Studies is indexed in the Index of Religious Periodical Literature

Printed in Great Britain at the

University Press, Cambridge 